\title{
Some Egyptian Background To The Old Testament*
}

\author{
by K. A. Kitchen, University of Liverpool
}

THE PURPOSE of this paper is simply to give formal demonstration of the antiquity of certain concepts, and of the antiquity and objective reality of certain usages: concepts and usages which were part of the common intellectual, religious and technical heritage of the Old Testament and Ancient Orient alike. Most of the comparative material is drawn from Egypt, insofar as Egypt is the best such source for, e.g., Israel's contacts with Egypt. However, on wider issues, material has sometimes been taken from other Bible lands too: this paper is in no way an exercise in 'pan-Egyptianism'.

\section{Personification}

\section{GERTAIN CONCEPTS}

Among the most notable passages in Proverbs are chapters viii-ix where Wisdom is personified. All too often this concept is labelled 'advanced' and cited as a reason for regarding that part of Proverbs as the latest in date, well after the Exile ${ }^{1}$. Personification here has even been linked with Greek influence ${ }^{2}$.

It is here suggested that late dating of the concept of personification as being 'advanced' is wholly mistaken, and appeal to Greek affinities entirely pointless, if decisive Ancient Near Eastern evidence be given its proper due. Personification of qualities, attributes and objects formed part of the common intellectual heritage of the Ancient Orient, of the Bible lands themselves, from as early as the 3 rd and 2nd millennia BC. Thus, on the single criterion of personification ${ }^{3}$, there is no

* This article is based on a paper read at the Old Testament Study Group, July 1959.

1 Typical is W. O. E. Oesterley, Proverbs, Westminster Comm., 1929, xiii, xxvi.

2 Eissfeldt, Einleitung in d.A.T.; Pfeiffer, Introduction to the OT, 1948, 659.

3 The other, linguistic, criteria often adduced for late date must be dealt with another time. 
compulsion or need to date Prov. i-ix any later than Solomon's time in the early ist millennium BC.

Egypt furnishes a number of personifications of concepts and qualities such as Wisdom. Already in the 3 rd millennium BC, Hike, 'Magic', is personified as a deity in human form in the funerary temple of Sahure ; in the Pyramid Texts (\$I324); and even in a priestly title 4 . In the 2nd millennium $B C$, examples multiply. Best-known are $\mathrm{Hu}$ and Sia, 'Authoritative Utterance' and 'Understanding' respectively, in the 3 rd and throughout the 2nd millennium $\mathrm{BC}^{5}$. In a very battered manuscript (c. $\mathrm{I} 320 \mathrm{BC}$ ) of the Middle Kingdom story of The Sporting King (c. I9oo BG) there occurs the double-barrelled personification Iir-Sedjmy, 'Sight-and-Hearing', a phenomenon paralleled at Canaanite Ugarit, see below 6 . Iret, 'Eye', features in a Mythological Story of the same date. The fourteen $k a s^{7}$ of the sun-god Rē, attested from the New Kingdom, c. I $500 \mathrm{BC}$, are shown by later texts to personify a whole series of qualities and states of being ${ }^{8}$.

That Egypt had no monopoly of this concept is clear from Western Asiatic documents. Mesopotamia yields a similar series of entities. In the early and millennium, if not before, the goddess Dam-gal-nun-na, wife of the god Enki or Ea, was thought to be served by two ministers Uznu and Khasisu, personifying 'Hearing' and 'Intelligence' respectively'. Likewise Namtaru, the messenger of the underworld goddess Ereshkigal, is the personification of the Sumerian Nam-tar, 'Destiny', in a legend on a Tell el-Amarna tablet of $c$. I36o BC'10. The underworld itself was sometimes personified as Irkallatu ${ }^{11}$. The personifications Kettu, 'Justice', and Mesharu, 'Law,

${ }^{4}$ A. H. Gardiner, Proceedings of Society of Biblical Archaeology, 37, (I9I 5), 253-262; ibid., 39, (1917), I 34-1 37 .

5 Gardiner, ibid., 38, (1916), 43-54, 83-95; ibid., 39, ( I9 1 7), I 38-9.

6 R. A. Caminos, Literary Fragments in the Hieratic Script, 1956, 35; and K. A. Kitchen, Fournal of Egyptian Archaeology, 44, ( 1958), 28.

"The " $k a$ " is a spiritual entity too complex to discuss here.

${ }^{8}$ Gardiner, Proc. Soc. Bibl. Arch., 38, (I916), 84. See further, J. Černý, Ancient Egyptian Religion, I952, 58-59; and esp. Gardiner, "Personification (Egyptian)", in Hastings, Encyclopaedia of Religion and Ethics, 9, 787-792.

9 E. Dhorme \& R. Dussaud, Les Religions de Babylonie . . . Assyrie . . . Hittites . . . etc., I 949, 37, 5 I.

10 Op. cit., 39-40, 52.

11 Loc. cit. 
Right', also date back to the 2nd millennium $\mathrm{BC}^{12}$. The Hurrians and Hittites were also familiar with such concepts: 'Sincerity' and 'Law, Justice' were personified ${ }^{13}$, and apparently 'Good' and 'Bad'14: The Babylonian Mesharu recurs in Hittite prayers of $c$. $1400 \mathrm{BC}^{15}$. The names of the divine bulls of the weather-god Teshup, Seri and Hurri, are Hurrian for 'Day' and 'Night' 16 Two other personifications are the 'Sea' ${ }^{17}$ and 'Torpor(?)'18.

From N. Syria the Canaanite texts from Ugarit also yield several personifications: one must suffice here - the artificergod, Kothar - w - Khasis, 'Skill - and - Understanding, Intelligence' ${ }^{19}$. The Hittite, Hurrian and Ugaritic sources all date from the $\mathrm{I}_{4}^{\text {th }}$ and $\mathrm{I} 3^{\text {th }}$ centuries $\mathrm{BC}$, i.e. well within the 2nd millennium.

The foregoing evidence, a selection only, should be amply sufficient to substantiate the claims made at the head of this section. It would be most fitting that Solomon should preface his proverbs proper with an introductory discourse (chapters $\mathrm{i}$-ix), as did some other sages of antiquity ${ }^{20}$; and in personifying Wisdom $c$. $950 \mathrm{BC}$, he would be using for the expression of divine truths, a figure of mind and speech very appropriate in a world where personification of concepts like wisdom - e.g. intelligence, understanding, authoritative utterance, justice, right, skill, etc. - had been familiar over wide areas of the Ancient East for well over a millennium before.

\section{Prediction as a Valid Concept}

Prediction of the future was regarded as a valid concept by the Egyptians during at any rate the period of the 22nd to $13^{\text {th }}$ centuries BC, or in Biblical terms from before Abraham down till Moses' time at least. The evidence comes firstly from

12 Op. cit., 67, 89 .

13 Op. cit., 34 o.

14 O. R. Gurney, The Hittites, Pelicans, 1952, 194.

${ }^{15}$ H. G. Güterbock, Fournal of American Oriental Society, 78, (1958), 241, 242, "the personified 'Order of Justice' ".

${ }^{16}$ Gurney, op. cit., I4I .

17 Gurney, op. cit., 192; Güterbock, The Song of Ullikummi, 1952, passim.

18 Gurney, op. cit., 187.

${ }^{19}$ C. H. Gordon, Ugaritic Manual, 1955, 282 ; Glossary No. 989 .

${ }^{20}$ So Ptahhotep and Amenemope in Egypt. 
explicit allusions in literary works and secondly from works which themselves were pseudo-prophecies, i.e. counterfeited a recognised concept.

Describing the break-up of Egypt after the Pyramid Age, the Admonitions of Ipuwer (23rd/22nd century BC) allude to 'that which the ancestors had predicted' 21 . The slightly later Teaching for King Merikarē also mentions a prediction of the ancestors and then exhorts him, 'Be not on bad terms with Upper Egypt, for you know about the prophecy of the Residence $^{22}$ concerning it' ${ }^{23}$. Later still, the Prophecy of Neferty from the early I 2 th Dynasty (c. I99o BC) is a pseudo-prophecy set in the reign of Snofru 700 years earlier but especially concerned to show forth the new dynast Amenemhat I as his country's appointed (political and social) saviour. That such pseudo-predictions should be deliberately produced argues directly for the validity of prediction in the eyes of contemporaries ${ }^{24}$. Some centuries later, in a New Kingdom work of about the $13^{\text {th }}$ century $\mathrm{BC}$, a writer extols the wisdom of the sages already ancient in his time and twice speaks of them having foretold the future ${ }^{25}$. From these examples, it is plain to see that the concept of prediction was quite acceptable among the Egyptians (as with the Hebrews), by contrast with the attitude adopted by some varieties of Old Testament scholar ${ }^{26}$.

\section{SOME PRAGTICES}

\section{Prefabricated Structures for Religious Use}

The Tabernacle which Moses and Israel were commissioned to construct at Sinai has been aptly characterised as 'a portable temple' ${ }^{27}$. Exodus xxvi and xxxvi describe its main features: a

${ }^{21}$ I:Io. G. Posener, Littérature et Politique dans l'Égypte de la XIIe Dynastie, 1956, 28; transl., Erman \& Blackman, Literature of the Ancient Egyptians, 1927, 94.

${ }^{22}$ A term for the pharaoh's palace.

${ }^{23}$ Posener, loc. cit.; Erman \& Blackman, op. cit., 79, or Pritchard, Ancient Near Eastern Texts rel. to OT, 1955, 416 .

${ }^{24}$ So also Posener, loc. cit. Transl., Erman \& Blackman, op. cit., 110-115 and in Pritchard, op. cit., 444-446 ("Neferrohu").

${ }^{25}$ Papyrus Chester Beatty IV, verso $2: 6,3: 7-8$, in Gardiner, Hieratic Papyri in the British Museum, 3rd Series, 1935, I, 38-9; II, Pls. 18-19.

${ }^{26}$ For modern times cf. F. F. Bruce, Acts of the Apostles: Greek Text, Introduction and Commentary, 1951, 13 and n.I on Savonarola and others.

${ }^{27}$ F. M. Cross, Biblical Archaeologist, 10:3, (1947), 6 1. 
series of vertical boards or frames ${ }^{28}$ each with tenons to fit into silver sockets, and linked along their length by bars through rings, all the acacia-wood being overlaid with gold. Four similarly wrought pillars supported a veil to screen-off the Holy of Holies. The whole was to be covered by dyed linen curtains coupled together with loops and clasps. Over these were placed successively coverings of goats' hair, rams' skins dyed red, and tahash, most probably worked leather ${ }^{29}$.

All too readily in the past, this structure has been dismissed as pure fantasy from the mind of some late priestly compiler ${ }^{30}$, or else as a late idealisation of some much simpler kind of tent in terms of Solomon's temple ${ }^{31}$. Of late, however, the existence of some kind of tent-shrine from Moses' time on has found favour with those scholars who adduce as a parallel, the much later pre-Islamic (and later) Arab tent-shrines such as the qubbah of red leather often carried on camel-back ${ }^{32}$.

Hitherto-neglected Egyptian evidence for prefabricated structures for religious and other uses definitively refutes the charge of late fantasy with very early examples of the constructional techniques so airily dismissed; this evidence at the same time provides a general background for portable structures much closer in most essentials than the very late and inexact parallels afforded by the old-Arabic qubbah.

Constructionally, the most striking item in the dossier is the splendid, prefabricated, portable bed-canopy of Queen Hetepheres I, mother of Kheops who built the Great Pyramid, ${ }^{28}$ Hebrew qerashim, taken by A. R. S. Kennedy, Hastings Dictionary of the Bible, IV, s.v. "Tabernacle", and McNeile, Exodus, (Westminster Comm.), diagrams at lxxxiv-v, as open frames rather than solid boards, of which the ends would still form tenons to fit the sockets.

${ }^{29}$ Heb. tahash is probably best derived from the old Egyptian word $t j-h-s$, "to treat leather", Erman \& Grapow, Wörterbuch d. Aeg. Sprache, V, 396, 7. So Bondi, Aegyptiaca, I-4, corrected by Griffith, in Petrie, Deshasheh, 1898, 45-6, and revived by Albright and Cross, Bibl. Archaeol., ro, (1947), 62 and n.22.

$30 \mathrm{~J}$. Wellhausen, Prolegomena to the History of Ancient Israel, Meridian ed., 1957, 39: "the tabernacle rests on an historical fiction" and "At the outset its very possibility is doubtful". A. Bentzen, Intr. to OT, II, 34: “... quite unrealistic. ."

31 So Galling, Exodus, 1939, I28ff. Also Cross, op. cit., 63-5, 68, who would allow an ornate Tabernacle as early as David's reign.

32 Cross, loc. cit.; the main studies on this are by H. Lammens, Bulletin de l'Institut Français d'Archéologie Orientale, I 7, (1919), 39-10 I, and J. Morgenstern, Hebrew Union College Annual, I 7, (1943), I 53-265; ibid., 18, (1944), I-52. 
c. $2600 \mathrm{BC}^{33}$. This remarkable structure is a framework of long beams along top and bottom separated by vertical rods and corner-posts on three sides of a rectangle, with a lintel beam and other horizontal 'roof-beams' across the top. The entire structure was of wood, was throughout overlaid with gold, had hooks for curtains all round, and consisted entirely of beams and rods fitting together with tenons in sockets for rapid and customary erection and dismantling, just like the Hebrew Tabernacle thirteen centuries later. Clearer evidence of the practicality and actual use at a remote age of the very constructional techniques exemplified by the Tabernacle could hardly be wished for. Moreover, this example is not isolated, and further material helps to span the long period between Hetepheres' canopy and Moses' tabernacle.

During the Archaic Period and Old Kingdom, Egypt's first great epochs ( $\left.c .285^{0}-2200 \mathrm{BC}\right)$, other similarly prefabricated structures are known from actual remains and tomb-scenes, and all more or less connected with religious usage ${ }^{34}$. Besides Hetepheres' own bed-canopy which may have been last erected over her coffin, and thus used as a funereal canopy, fragments of canopy poles were found in a royal tomb of the Ist Dynasty at Saqqara ${ }^{35}$, taking the history of these structures back to the 29th century BC. Four further canopies are depicted in sculptured tomb-chapels of the $4^{\text {th }}, 5^{\text {th }}$, and 6th Dynasties (c. 2600-2200 BC) ${ }^{36}$.

A second form of prefabricated structure from the $3^{\text {rd mil- }}$ lennium is relevant not only constructionally but also as having a specifically religious function. This is the Tent of Purification (ibw) to which the corpses of royal and exalted personages were borne for the rituals of purification both before and after embalmment. From pictures in Old Kingdom tombs, it is clear that these portable 'tents' were sizeable structures having hangings of cloth (like curtaining) upon a framework of vertical

${ }^{33}$ G. A. Reisner and W. S. Smith, A History of the Giza Necropolis, II, 1955, the splendid final publication. More accessible pictures in L. Cottrell, The Lost Pharaohs, 1950, fig. 23 opp. p. 128, or W. S. Smith, Art and Architecture of Ancient Egypt, 1958, Pls. 30, a; 34 .

${ }^{34}$ Reisner and Smith, op. cit., I4-15.

${ }^{35}$ W. B. Emery, Great Tombs of the First Dynasty, I, 1949, 58, fig. 30.

${ }^{36}$ Reisner and Smith, op. cit., 14 for references. 
poles or pillars linked along the top by horizontal bars and beams - again, directly reminiscent of the Tabernacle ${ }^{37}$. In conjunction with these edifices, a similar one, the sh, 'booth', was used to shelter funerary equipment or the food-offerings for a funerary banquet, all in a religious context. Besides the representations already mentioned, actual remains of at least two of these 'tents' appear to have been recovered. Earliest are wooden fragments from a store-chamber among buildings attached to the Step Pyramid of the 3rd Dynasty king Djoser, c. $265^{\circ} \mathrm{BC}^{38}$. Then, from the tomb-shaft of Queen Hetepheres were recovered fragments of gilded wooden poles or pillars, copper fittings and limestone sockets for the pillars: the same techniques all over again ${ }^{39}$.

From the Middle Kingdom (c. 2000-I570 BC), contemporary with the Patriarchs, the evidence is at present less direct, but see just below.

The remaining evidence comes mainly from the 18 th and I 9 th Dynasties, c. I570-I $200 \mathrm{BC}$, i.e. during the period of Israel's Egyptian sojourn and including the lifetime of Moses

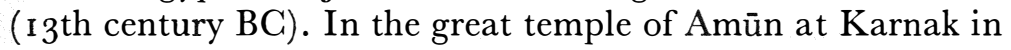
Thebes, Tuthmosis III (c. I470 BC) erected a great Festival Hall, a translation into stone of a large tent-structure supported on wooden pillars whose special forms were imitated ${ }^{40}$. It appears to be linked with the 'Sed'-festival, celebrated to obtain renewal of a king's powers. In that festival, at all periods from the ist Dynasty through the Old, Middle and New Kingdoms down to the end of Egyptian history, its special rituals seem to have required light pillared pavilions on daises, which could be put up for the occasion and then dismantled again.

In the tombs of the New Kingdom pharaohs it was customary to instal at burial four great prefabricated wooden shrines, gold-overlaid, which were nested concentrically over the coffins of the dead pharaoh. The only complete set surviving

${ }^{37}$ B. Grdseloff, Das Aegyptische Reinigungszelt, I941, plus E. Drioton, Annales du Service des Antiquités de l'Égypte, 40, (1940), r 008 . Good pictures of "Tent of Purification" showing construction in Blackman, Rock Tombs of Meir, V, I952, Pls. 42, 43 .

${ }^{38}$ Reisner and Smith, loc. cit.

39 Loc. cit. with $\mathrm{Pl} .3$.

${ }^{40}$ Lange and Hirmer, Egypt, Phaidon, I 956, Pls. 1 37-9. 
comes from the tomb of Tutankhamūn, c. I 340 BC, only shortly before Moses' time ${ }^{41}$. Each shrine is rectangular, roofed, and has double doors at one end; each was prefabricated in several sections which were then assembled in the king's tomb. These sections fitted together with tenon-andmortise joints and dowels, and the woodwork was overlaid with gold throughout. The largest shrine was about $16 \frac{1}{2}$ feet long by I I feet wide by 9 feet high.

For the portable tent-structure strategically placed in the centre of a rectangular camp of the tribes (cf. Nu. ii, $\mathrm{x}$ ), the abode of Israel's sole Sovereign with His people, it is significant to note that the same strategic layout was utilised by Moses' contemporary Ramesses II in his Syrian campaigning; the divine king's large portable war-tent was pitched in the centre of a rectangular encampment of the army-divisions ${ }^{42}$. Perhaps in this Moses exploited his Egyptian training in the service of his God and nation. It is especially noteworthy that this Egyptian comparison should come from the very century in which Moses lived. Later, in the ist millennium, such military camps apparently changed their shape: those shown on Assyrian royal reliefs are round ${ }^{43}$. That tabernacular structures for religious purposes were not wholly peculiar to Egypt is perhaps indicated in the Ugaritic story of King Krt who performs certain rituals in a tent ${ }^{44}$.

The upshot of all this is quite clear. The methods of construction employed and the use of such prefabricated structures for religious purposes are abundantly attested by actual remains, pictures and texts in Egypt over a long period of time, many examples long pre-dating Moses. Hence it is now entirely unnecessary to dismiss either the concept or construction of the Tabernacle of Ex. xxvi, xxxvi as fantasy or free idealisation. The Egyptian data here adduced cannot of course directly prove the early existence of that Tabernacle, but it does create a very strong presumption in favour of the reasonableness and veracity of the straightforward Biblical account.

${ }^{41}$ Most accessible photos, P. Fox, Tutankhamūn's Treasure, I95I, Pls. 18 and 21 .

${ }^{42}$ E.g. Battle of Qadesh, c. 1285 BC: Ch. Kuentz, La Bataille de Qadech,1928-34,

Pls. 34, 39, 42 .

43 Cf. G. Contenau, Everyday Life in Babylon and Assyria, 1954, Pl. 17.

${ }^{44}$ So C. H. Gordon, Ugaritic Literature, 1949, 5-6, and 71 (Krt, 159ff). 


\section{Possibility of Hebrew Artisans at the Exodus}

In connection with the Tabernacle, it is sometimes objected that as a subject-race before the Exodus, the Hebrews would have no skills such as the work of the Tabernacle required, and could hardly have obtained the necessary materials even from spoiling the Egyptians ${ }^{45}$. However, this is far from being necessarily the case. Although many Semites in Egypt were put to forced labour on brickmaking ${ }^{46}$, and transporting stone for buildings ${ }^{47}$, some had other occupations.

During the New Kingdom, period of the Sojourn and Exodus, there is ample if somewhat generalised evidence for varied employment of foreign slaves, especially in the workshops and stores ('ergastula') attached to temples and government institutions ${ }^{48}$. Instead of dragging stone, some Apiru are to be found more congenially employed as vintners ${ }^{49}$. Numerous tomb-scenes show ${ }^{50}$ how greatly the Egyptians prized Semitic craftsmanship in precious metals when exacting tribute from Syria-Palestine - and among the many Semites captive in Egypt, craftsmen would be no less valued. Such Semites could rise to official posts ${ }^{51}$ and in Ramesses II's reign some were even trained for office ${ }^{52}$. The wealth of Egypt available in the E. Delta in the $13^{\text {th }}$ century BC must have been very considerable, for Pi-Ramessē, Ramesses II's opulent Delta capital was situated there in a prosperous region whose wonders were lyrically praised by contemporary scribes ${ }^{53}$.

In view of these indications various skills would be represented among the Hebrews and 'mixed multitude' who left Egypt; amply sufficient skills to furnish a Bezalel and an

${ }^{45}$ S. R. Driver, Exodus (Cambs. Bible for Schools), 1911, 426-7; McNeile, Exodus, (Westm. Comm.), lxxxi.

46 See D. J. Wiseman, Illustrations from Biblical Archaeology, 1958, 44-5, fig. 38.

47 Mention of Egyptians and 'Apiru 'who drag stone to the great pylon', Caminos, Late Egyptian Miscellanies, 1954, 491.

48 A. M. Bakir, Slavery in Pharaonic Egypt, 1952, 44-45, 1 10-1 1 5; Gardiner, Ancient Egyptian Onomastica, II, 1947, 209*-2 10*, No. 430; G. Posener, Syria, 18, (1937), 183-197.

49 T. Säve-Söderbergh, Orientalia Suecana, 1, (1952), 5-14.

50 E.g. Wiseman, op. cit., fig. 29, opp. p. 34.

51 J. M. A. Janssen, Chronique d'Egypte, 26, (1951), 50-62.

$52 \mathrm{~S}$. Sauneron and J. Yoyotte, Revue d'Egyptologie, 7, (1950), 67-70.

ss Caminos, op. cit., 37-8, 73-4, 101, and cf. 198-201. Abridged, Pritchard, Anc. N.E. Texts, 470-1. 
Oholiab, and from the Egyptians in the E. Delta at that particular epoch spoils (Ex. xii, 35-36) amply sufficient for the work of the Tabernacle.

\section{Agricultural Statutes before Settlement in Canaan}

It has sometimes been suggested that the provision in the Pentateuchal laws for the regulation of agricultural and settled life could not antedate Israel's settlement in Canaan, or have been given at Sinai where it would be irrelevant to nomads ${ }^{54}$. However, this view fails to allow for a whole series of facts which make it much more prudent to retain the Biblical account of Moses legislating intelligently for imminent occupation of Canaan.

Firstly, from the start, there is no evidence that the Hebrews were ever nomads in the conventional modern sense of desert Bedouin. Ur of the Chaldees was a typical urban community based directly on a thoroughly agricultural and pastoral economy, as throughout early Mesopotamia ${ }^{55}$ : hence, the Patriarchs could be pastoralists and agriculturalists from the outset. All round the so-called Fertile Crescent, semi-nomadic people with their flocks and herds were to be found moving slowly past or between the cultivated fields of the settled agricultural populations ${ }^{56}$, and sometimes themselves engaging in some modest grain-growing or even settling down ${ }^{57}$. It is thus no surprise to see Isaac growing an odd season's grain in Gen. xxvi, I $2^{58}$, or to find Joseph's first dream set in the harvest-field, Gen. xxxvii, 6-7. On this combined Biblical and extra-biblical evidence, even the Patriarchs were by no means simple desert nomads on the eve of their entering Egypt.

54 Wellhausen, Prolegomena ..., I957 ed., 93: "Agriculture was learned by the Hebrews from the Canaanites in whose land they settled, and in commingling with whom they . . . made the transition to a sedentary life." And likewise some more recent writers.

55 Cf. H. Frankfort, Birth of Civilization in the Near East, 1951, 57ff, and ch. III generally; the modern contrast between town and country was meaningless in early Mesopotamia.

56 See statement of "ass-semi-nomadism" in Albright, Archaeology and Religion of Israel, 1953, 96-102; but note that camels, domesticated, are now attested in an 18th century BC ration-list from Alalakh, Wiseman, Fournal of Cuneiform Studies, I 3, (1959), 29 (269:59, GAM.*MAL*), and A. Goetze, ibid., 37.

${ }^{57}$ Cf. J. R. Kupper, Les Nomades en Mésopotamie au Temps des Rois de Mari, 1 957, 3 I, 59, 75, 77, 9 I, 98-9, etc.

58 As noted by C. H. Gordon, Introduction to OT Times, I I 3. 
It is at this point that conditions in the Egyptian E. Delta become relevant. For 430 years, Israel lived and multiplied in that area. During that entire period they lived in a prosperous region famed alike for its cultivated crops, its rich pastures and its marshes full of game-birds and fish ${ }^{59}$. It is inconceivable that Israel should fail to gain agricultural experience, having begun some crop-growing before entering Egypt and being constantly confronted with its practice for four centuries thereafter. Deut. xi, ro indicates that in fact Israel did respond to conditions in Egypt. Furthermore, there was every facility for the inhabitants of the E. Delta to know of conditions in nearby Canaan: there was constant coming and going over the frontier ${ }^{60}$ by both Egyptians and Semites ${ }^{61}$. Hence, there is no reason why Moses or anyone else in his position should not have been able to plan for life in agricultural Canaan.

Finally it is important to remember that when the agricultural regulations in Ex. xxi-xxiii, etc. were proclaimed at Sinai, Israel then anticipated speedy settlement in Canaan; it was only after this that they brought upon themselves the judgement of 40 years' sojourn in the wilderness, Nu. xiv, 26-35. Likewise, references in Deuteronomy to agriculture, living in houses, etc. must be considered against the occupation of Transjordan by two and a half tribes before Moses' oration and death, and against four centuries' sedentary life in Egypt.

Thus the Biblical references and the Egyptian and allied background together provide a clear and realistic picture which we are not entitled to doubt in the absence of any objective external data to justify such doubts.

\section{SOME LITERARY BACKGROUND}

\section{Transmission of Family Records for Long Periods}

It is often assumed that written family records concerning the Patriarchs may have been handed down from Joseph's time through the four centuries of the Hebrew sojourn until Moses' day, and that such records were used by Moses and so lie

${ }^{59}$ Lyrical scribal descriptions of Pi-Ramessē area, Caminos, L. Eg. Miscell., 73-4 (Anc. N. E. Texts, 470-1); cattle and crops, Caminos, op. cit., 307.

${ }^{60}$ Ibid., 108-9 for the journal of a frontier-official (Anc. N. E. T., 258-9).

${ }^{61}$ Ibid., 293 (A.N.E.T., 259) for Edomite tribesfolk entering the Succoth region for pasture. Runaway slaves escaping from Egypt, ibid., 255 (A.N.E.T., 259). 
behind the present book of Genesis ${ }^{62}$. Some indirect support for this thesis can be obtained from Egyptian sources which show clearly that transmission of family records over long periods of time was perfectly practicable. This evidence comes from genealogies and legal documents.

Genealogies. At least seven ${ }^{63}$ long genealogies are known, each spanning several centuries; they vary in date from the 2oth to the $4^{\text {th }}$ centuries BC - in Biblical terms, from the age of the Patriarchs to that of the Persians. They usually give the names and titles in the male line, and sometimes the wives are also named.

I. Ukhhotep, son of Ukhhotep and Mersi, was a Count of the I 4 th Upper Egyptian nome (province) who lived in the reign of the I 2th-Dynasty king Amenemhat II, c. I925 BC, the period of Abraham. In his tomb-chapel, he had sculptured a complete list of his 59 forebears and predecessors-in-office with their wives, each by name and apparently in chronological order ${ }^{64}$. The earliest ancestor of the series seems to have lived in the $4^{\text {th }}$ Dynasty c. $2500 \mathrm{BC}$, so this record spans about 600 years, or half as long again as the four centuries from Joseph to Moses. The differing styles of the names indicate the genuineness of this document.

2. On a slab in the Berlin Museum ${ }^{65}$ one Ankhef-enSekhmet, a priest of Ptah and Sekhmet, and living late in the 22nd Dynasty at $c$. 800/750 BC, traces back his ancestry for 60 generations far back to the distant reign of Nebhepetre Mentuhotep I of the I Ith Dynasty, c. 2050 BC, covering thus the incredible span of some 1300 years. This is more than thrice the length of the four centuries' period from Joseph to Moses. At intervals, the names of contemporary kings are mentioned, the later part of the document is confirmed by two independent monuments in Cairo and Paris, and the names fit

${ }^{62}$ E.g., J. Astruc, Conjectures sur les Mémoires ... que Moyse s'est servi ..., I 753 ; P. J. Wiseman, New Discoveries in Babylonia about Genesis, 1948, 79-89; J. S. Wright, How Moses Compiled Genesis-A Suggestion.

${ }^{63}$ An eighth of late date and very incomplete is preserved in the Ny Carlsberg Museum, Copenhagen.

${ }^{64}$ Blackman, Rock Tombs of Meir, III, 1915, I6-21, Pls. 10, II, 29, 33:I, 35:I, 36:1, 37:1, 2. Further studied by L. Borchardt, Die Mittel zur Zeitlichen Festlegung von Punkten der Ägyptischen Geschichte und ihre Anwendung, 1935, 112-114.

${ }^{65}$ Fully edited by Borchardt, op. cit., 96-1 12 with Pls. 2, 2 a. 
the periods assigned them, so that the genuineness of this record also is beyond doubt. That these two genealogies, if remarkable, are not unique is shown by the existence of the following five examples.

3. Harkhebit, a priest who apparently lived $c .700 \mathrm{BC}$ in the general period the 22nd to 26th Dynasties, has left record of I 7 lineal ancestors reaching back to the late i 8 th Dynasty c. I350 $\mathrm{BC}$, and so spanning roughly $65^{0}$ years ${ }^{6}$.

$4 \& 5$. In the $3^{\text {rd }}$ year of the $25^{\text {th }}$ Dynasty king Tanutamūn c. 66 I BC, two newly-inducted priests exhibited their ecclesiastical pedigrees by leaving a record of $\mathrm{I} 3$ ancestors in the one case and $\mathrm{I} 6$ in the other, reaching back some 340 to 400 years to between 1000 and I Ioo $\mathrm{BC}^{67}$.

6. When visiting the quarries in Wady Hammamat in the desert E. of the Nile in the 26 th year of Darius I (c. $496 \mathrm{BC})$, the chief architect Khnumibrē left a long record of 22 ancestors extending back at least $75^{\circ}$ years to the time of Ramesses II of the I 9 th Dynasty ${ }^{68}$. Besides its value in the present connection (long transmission), this genealogy is of interest in covering about the same span of time as that of the Hebrew high priests in the Old Testament; like theirs it also shows several repetitions of certain names in various generations. Such repetitions merely illustrate the sustained popularity of such names over a period and must not be dismissed as mere doublets in either case.

7. Finally, a slab from the tomb of Patjenef, a high priest in Heliopolis (Biblical On) who lived in the 3oth Dynasty c. $35^{\circ} \mathrm{BC}$, shows him offering to $\mathrm{I} 2$ ancestors, 'his fathers and mothers', who probably covered some 400 years back to c. 700 or $75^{\circ} \mathrm{BC}^{69}$.

These examples all show the feasibility of accurate transmission of family lineage over very long periods of time, and are comparable in general style with the 'toledoth', 'generations', of Gen. v and xi. The legal documents next to be cited show a

${ }^{66}$ Hieratic stela, Mariette, Karnak, I875, Pl. 46, transcribed by Spiegelberg,

Proc. Soc. Bibl. Arch., 24, (1902), 320-4.

${ }^{67}$ Borchardt, op. cit., 93-4 with references.

68 Couyat and Montet, Les Inscriptions Hiéroglyphiques ... du Ouadi Hammamat, 191 2, 67-9, Pl. 22, Nos. 91, 93-92. Borchardt, op. cit., 95-6.

${ }^{69} \mathrm{~F}$. Ll. Griffith, The Antiquities of Tell el Yahudiyeh, I890, 67-8 and Pl. 22, A. 
like transmission of other details besides just personal names.

\section{Legal Documents}

I. The sale of the Countship of Nekheb (now El Kab, in Upper Egypt) by one Kebsi to his relative Sobknakht in settlement of a debt, dated to the ist year of Nebiryerau I (c.I66o/ I65o BC). Before consummation of the sale, Kebsi's title to his Countship had to be verified; and documents were examined and cited to confirm that it had come down to him in due legal form from his grandfather who received the Countship in the Ist year of Sobkhotep VI some 40/6o years earlier. The transmission and availability of the legal documents consulted was noteworthy in that the seizure of power by the Hyksos or 'Shepherd Kings' and consequent transfer of the centre of the native Egyptian administration from Memphis to Thebes had all happened between the drawing-up of the first documents and their consultation at the time of Kebsi's sale. This episode falls into roughly the same period as Joseph. ${ }^{70}$

2. The inscription of $\mathrm{Mes}^{71}$. This text is a summary of long litigation over ownership of some land, which had involved the production or citation of registers and documents relating to the original grant of the land far back in the days of Ahmose I (I570-I550 BC). The final lawsuit of Mes, the outcome of which occasioned the inscription, took place some years after the I8th year of Ramesses II, i.e. after $c$. I $270 \mathrm{BC}$, giving a span of 300 years from the original land-grant and first records down to Mes's final lawsuit to recover his inheritance. The people involved were private individuals of comfortable station, holding positions connected with the royal administration. This text shows clearly that documents or record of documents were kept over centuries; and that even when such were stored in official archives, the people whose interests they recorded could readily gain access to them when need arose, even though they themselves were just ordinary officials, though by no means illiterate peasants. This text of Mes is the more relevant because it covers most of the very same period which elapsed between Joseph and Moses, and is thus a strictly contemporary example of transmission.

${ }^{70}$ Published by P. Lacau, Une Stèle Juridique de Karnak, 1949.

71 Gardiner, The Inscription of Mes, in Untersuchungen, IV:3, 1905. 
In the light of this varied evidence, it is clear that Joseph as a high minister of state in Egypt would have every facility for recording patriarchal traditions of his forebears, and for transmitting them through the hands of his descendants until Moses' time. Such records need not even have been written in Egyptian; the proto-Sinaitic script was already available for use with Joseph's own West-Semitic dialect?2. Good papyrus made quite durable documents: witness the sheet from the criminal-register of the prison at Thebes which after 70 year's use at different times still served to record a bequest of servants $^{73}$. And many Egyptian papyri have survived untold centuries to the present day in good condition. So, any documents for which Joseph might have been responsible could readily have survived until Moses' time, with or without occasional recopying. The data here adduced cannot actually prove that such a transmission occurred - but it does create a strong presumption in favour of some such view.

The above brief studies are but a puny handful of points from the great store of information furnished by Egypt and Western Asia. On Egypt and the Old Testament, and on unexplored tracts in the realm of the literary background provided by Egyptian and other texts for study of the structure of the Old Testament, it is hoped to produce further and fuller works in the reasonably near future.

72 The Shechem Plaque, about the earliest known example at present, dates from c. $1800 \mathrm{BC}$

${ }^{73}$ W. C. Hayes, A Papyrus of the Late Middle Kingdom in the Brooklyn Museum, 1955; its relevance to Joseph's day briefly appreciated, Kitchen, Tyndale House Bulletin, No. 2, (1957), 1-2. 